\title{
Examining of Financial Performance Sharia Life Insurance the Role of Intellectual Capital Case Study: Indonesia
}

\author{
I F Rahmatunnisa ${ }^{1}$, Sumiyati $^{2}$ \\ \{irmafiki@gmail.com ${ }^{1}$, sumiyati@polban.ac.id $\left.{ }^{2}\right\}$ \\ ${ }^{1,2}$ Applied Master of Islamic Finance and Banking, Bandung State Polytetchnic, Indonesia
}

\begin{abstract}
This study aims to determine the effect of Return on Assets (ROA), Operational Costs (BOPO), Liquidity, Loss Ratio, Size and Volume of Capital (VOC) on Intellectual Capital Sharia Life Insurance Companies in Indonesia as measured by VAIC ${ }^{\mathrm{TM}}$. The analysis technique used is multiple linear regression using monthly data from February 2015 - April 2018 sourced from OJK. The results of the study show that BOPO, Liquidity, and Size have a significant effect on VAIC $^{\text {TM }}$ while ROA, VOC and Loss Ratio have no significant effect on VAIC $^{\text {TM }}$
\end{abstract}

Keywords: Intellectual Capital, VAICTM, Sharia Life Insurance, Financial Performance

\section{Introduction}

The insurance sector has an important role in a service-based economy. As a financial intermediary institution that has been integrated into the broader financial industry [1]. According to Hasbi [2], the problems that occur in sharia-based insurance financial instruments are due to the lack of interest in insurance products or the low financial performance of sharia-based insurance companies so that there's a lack of public trust in sharia-based insurance. And this can be improved by doing the best performance. A state that companies in Indonesia will be able to compete if they use the competitive advantage gained through creative innovations produced by the company's intellectual capital [3]. Disclosure of the role of intellectual capital as new wealth creates conceptual dynamics about human resources. [4] intellectual capital as a total share of the collective knowledge, information, technology, intellectual property rights, experience, organizational learning and competencies, team communication systems, customer relations, and brands that are capable of creating corporate value. Instructions for managing intangible assets and facilitating success through ongoing competitive advantage to lead companies and organizations.

The intellectual capital theory is challenged skeptically when faced with the paradigm of a traditional accounting model that believes that industrial economics remains focused on financial and physical assets and ignores intellectual capital assets. But in 1997, Public [5] provided a solution to this by developing the VAICTM model which is an instrument or model to measure the performance of the company's intellectual capital [6].

In its implementation, intellectual capital is something new, not only in Indonesia and even in the global business environment. Nevertheless, the Public model remains a research study that is still very interesting and is still great concern of academic from various scientific 
disciplines [7]. In Indonesia, research to examine the relationship between VAICTM and the company's financial performance has been done using different types of industries. Budi and Ahmad [8] examined the effect of intellectual capital gains with empirical studies of banks listed on the Indonesian stock exchange. Ulum, et al [9] examined the construction of performance measurement models and disclosure frameworks for intellectual models. Ulum [10] examined the disclosure of the intellectual capital model in the performance of the banking sector in Indonesia.

Cheng and Hwang [11] examined the effect of corporate intellectual capital on market value and financial performance and possibilities as indicators for future financial performance using companies listed in Taiwan. The next stage is for researchers to expand their research domain by analyzing non-profit institutions. Some of them like Rehman and Zahid [12] by testing the performance of intellectual capital in non-profit companies (modaraba companies) and their influence on company performance using measures of Return on Equity (ROE), Return on Investment (ROI) and Earnings per Share (EPS).

And then, Petty and Guthrie [7] also conducted research on Intellectual Capital and Value: Challenges in the Voluntary Disclosure of Value Drivers. In 2007, Appuhami [11] researched the Impact of Intellectual Capital on Investors' Capital Gains on Shares: An Empirical Investigation of Thai Banking, Finance \& Insurance Sector, which aims to investigate the impact of efficiency value creation on investor capital gains on shares. And to investigate the impact of value creation efficiency companies on investor capital gains.

And Intellectual Capital research was conducted by Osama and Fatimah [7] who conducted research in the field of Islamic banking, namely Intellectual Capital and financial performing Islamic banks, which found that if the Intellectual Capital and optimal resources would improve financial performance.

Ulum [6] wrote Value Added Method of Intellectual Capital Coefficient (VAICTM) was developed by Pulic in 1997 which was designed to present information about value creation efficiency of tangible assets and Intangible Asset owned by the company. VAICTM is an instrument for measuring the performance of a company's intellectual capital.

Thus it can be concluded that some previous studies have succeeded in revealing the existence of a significant relationship between intellectual capitals on the company's financial performance. Company performance is used as a research variable because parties such as stakeholders, academics and policymakers make it a foothold to describe various parts of the entire company from the financial side itself until the output level on market returns.

Based on this, the discussion of intellectual capital disclosure and its effect on the financial performance of insurance companies in Indonesia is an interesting thing to do. Moreover, insurance companies in Indonesia are currently developing very rapidly due to the encouragement of public awareness about the importance of insurance that provides investment facilities, preventive self-protection, and property. And this is shown by the growth of assets in sharia life insurance companies in Indonesia.

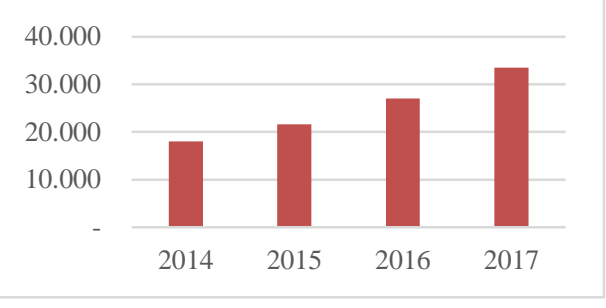

Figure 1 : Asset Growth of Sharia Life Insurance Companies in Indonesia 2014-2017 
The growth of the Islamic finance industry, especially sharia life insurance, is not only indicated by the quantity of sharia life insurance companies in Indonesia. However, this development is also indicated by the development of assets in sharia life insurance companies in Indonesia. Can be seen in Figure 1.1 above, Which in 2014 Sharia life insurance assets reached 18,052 Billion which increased by around 3,526 Billion in 2015. And in 2016 fixed assets continued to increase to 27,079 Billion and by the end of 2017 assets in Sharia life insurance reached the value of 33,534 Billion or $24 \%$. And the highest asset development was achieved in 2016, where assets increased by $25 \%$ from the previous year. Asset growth continues to increase from year to year which shows increased public confidence in the industry.

The purpose of this study is to empirically examine the effect of Return on Assets (ROA), Operational Costs (BOPO), Liquidity, Loss Ratio Volume of Capital (VOC) and Size on Intellectual Capital sharia life insurance companies in Indonesia. And it is hoped that this research can contribute to science especially for researchers, stockholders, regulators, and the community.

\section{Literature Review}

\begin{tabular}{|c|c|c|}
\hline No & Variabel & Formula \\
\hline 1 & Intellectual Capital & $\begin{array}{l}\mathrm{VAIC}^{\mathrm{TM}}=\mathrm{VACE}+\mathrm{VAHC}+ \\
\text { STVA }\end{array}$ \\
\hline 2 & $\begin{array}{l}\text { Return On Asset } \\
\text { (ROA) }\end{array}$ & ROA = Net Profit $/$ Total Asset \\
\hline 3 & $\begin{array}{l}\text { Operational Cost } \\
\text { (BOPO) }\end{array}$ & $\begin{array}{l}\mathrm{BOPO}=\text { Operational Cost/ } \\
\text { Operational Income }\end{array}$ \\
\hline 4 & Liquidity & $\begin{array}{l}\text { Liquidity = Current Asset / } \\
\text { Current Liabilitas }\end{array}$ \\
\hline 5 & Loss Ratio & $\begin{array}{l}\text { Loss Ratio = Net Claim / Net } \\
\text { Earned Premium }\end{array}$ \\
\hline 6 & Size & Size $=$ Log Natural Total Asset \\
\hline 7 & $\begin{array}{l}\text { Volume Of Capital } \\
\text { (VOC) }\end{array}$ & $\begin{array}{l}\text { VOC = Log Natural Book } \\
\text { Volume of Capital }\end{array}$ \\
\hline
\end{tabular}

The stages of calculating $\mathrm{VAIC}^{\mathrm{TM}}$ are as follows :

$$
\text { * VA = OUT - IN }
$$

Explanation:

VA : Value Added

OUT (Output) : Total Income /Other Income

IN (Input) : Cost of Sales and Other Cost (exclude employe cost)

$$
\begin{array}{ll} 
& \text { VACE }=\text { VA } / \text { CE } \\
\text { Explanation: } \\
\text { VA } \quad \text { : Vallue Added } \\
\text { CE } \quad \text { Total Equity } \\
\\
\text { *AHC }=\text { VA } / \text { HC }
\end{array}
$$


VA : Vallue Added

HC : Human Capital Cost

* STVA = SC- VA

Explanation:

SC : Structural Capital : VA - HC

VA : Vallue Added

- VAIC $\quad$ VACE + VAHC + STVA

Explanation:

$\mathrm{VAIC}^{\mathrm{TM}}=$ Intellectual Capital

\section{Method}

The method used is descriptive analysis with multiple linear regression statical test techniques because the data studied is a ratio scale. The software of analysis uses Eviews version 9. The data used in this study are secondary data from a monthly data period from February 2015 - April 2018 sourced from Financial Service Authority (OJK - Otoritas Jasa Keuangan).

While the operationalization of variables is explained through the following table:

\begin{tabular}{|c|l|c|c|}
\hline $\begin{array}{c}\text { Type } \\
\text { Variabel }\end{array}$ & \multicolumn{1}{|c|}{ Information } & Variable & Symbol \\
\hline Dependent & Intellectual Capital & VAIC $^{\mathrm{TM}}$ & $\mathrm{Y}$ \\
\hline \multirow{5}{*}{ Independent } & Return On Asset & ROA & $\mathrm{X}_{1}$ \\
\cline { 2 - 4 } & Operational Costs & BOPO & $\mathrm{X}_{2}$ \\
\cline { 2 - 4 } & Liquidity & Liquidity & $\mathrm{X}_{3}$ \\
\cline { 2 - 4 } & Loss Ratio & Loss Ratio & $\mathrm{X}_{4}$ \\
\cline { 2 - 4 } & $\begin{array}{l}\text { Volume } \\
\text { Capital }\end{array}$ & CAP & $\mathrm{X}_{5}$ \\
\cline { 2 - 5 } & Size & SZ & $\mathrm{X}_{6}$ \\
\hline
\end{tabular}

Table I. Operationalization Of Variables

The multiple linear regression is determined using the following equation:

$Y=a+b_{1} X_{1}+b_{2} X_{2}+b_{3} X_{3}+b_{4} X_{4}+b_{5} X_{5}+b_{6} X_{6}$

Where :

$Y$ : Dependent Variables

$X$ : Independent Variables

$a$ : Intercept Constanta

$b$ : Coefficientt Regression 


\section{Result and Discussion}

The following research contains several management mechanisms for software projects Before multiple linear regression analysis is carried out, it must first do a classic assumption test to ensure all requirements have been met.

a. Residuals Normality Test

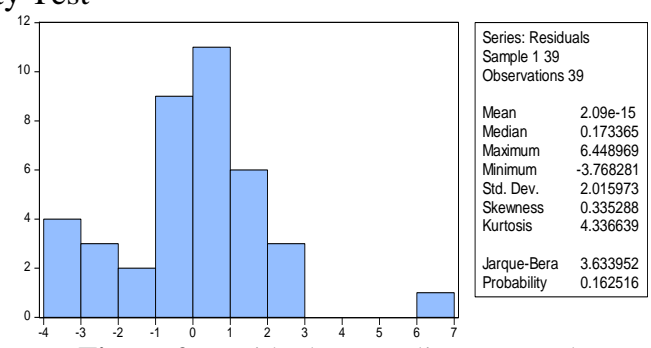

Figure 2 .Residuals normality test result

In the figure, it can be seen that the Jarque-Bera value is 3.633952 with $p$ value of 0.162516 or $\mathrm{p}$ value $>0.05$. Which means the data is normal so that research can continue.

b. Multicolinearity Test

\begin{tabular}{|c|c|c|c|}
\hline & $\begin{array}{c}\text { Coeffici } \\
\text { ent }\end{array}$ & $\begin{array}{c}\text { Uncenter } \\
\text { ed }\end{array}$ & Centered \\
\hline Variable & Variance & VIF & VIF \\
\hline & & & \\
\hline & 1537.84 & 12427.2 & NA \\
& 9 & 6 & \\
\hline ROA & 93.0818 & 4.70174 & 2.50962 \\
& 5 & 7 & 8 \\
\hline BOPO & 52.1686 & 102.990 & 9.18954 \\
& 3 & 9 & 7 \\
\hline LIQUIDITY & 2.97346 & 15.0597 & 5.98441 \\
& 6 & 2 & 7 \\
\hline LOSS_RATIO & 20.9376 & 78.3767 & 8.03573 \\
& 2 & 1 & 0 \\
\hline CAP & 9.67725 & 3970.50 & 5.38831 \\
& 1 & 0 & 4 \\
\hline SZ & 19.3627 & 16143.5 & 6.42913 \\
& 2 & 0 & 3 \\
\hline
\end{tabular}

Figure 3. Multicolinearity test result

In the picture, it can be seen that the Centered VIF value of all variables is less than 10 , so it can be stated that there is no multicollinearity problem in the prediction model.

c. Heteroskedasticity Test

\begin{tabular}{|l|r|cc|r|}
\hline Heteroskedasticity Test: Breusch-Pagan-Godfrey \\
\hline F-statistic & 1.685 & Prob. F(6,32) & 0.156 \\
& 826 & & & 6 \\
\hline Obs*R- & 9.366 & Prob. & Chi- & 0.154 \\
squared & 820 & Square(6) & & 0 \\
\hline Scaled & 10.52 & Prob. Chi- & 0.104 \\
explained SS & 064 & Square(6) & & 4 \\
\cline { 1 - 4 }
\end{tabular}

Figure 4.Heteroskedasticity test result 
In the picture, it appears that the $\mathrm{p}$ value is indicated by the value of the Prob. chi square (2) in Obs * R-Squared which is equal to 0.1540 . Because the p-value is $0.1540>0.05$, it means that the regression model is homoscedasticity or in other words there is no problem with the assumption of non-heteroscedasticity.

d. Multiple Linear Regression Analysis

\begin{tabular}{ccccc}
\hline \hline Variable & Coefficient & Std. Error & t-Statistic & Prob. \\
\hline \hline C & -196.3297 & 39.21541 & -5.006443 & 0.0000 \\
ROA & -9.901110 & 9.647894 & -1.026246 & 0.3125 \\
BOPO & -69.80125 & 7.222786 & -9.664034 & 0.0000 \\
LIQUIDITY & -5.227143 & 1.724374 & -3.031328 & 0.0048 \\
LOSS_RATIO & -0.387074 & 4.575765 & -0.084592 & 0.9331 \\
CAP & -3.354975 & 3.110828 & -1.078483 & 0.2889 \\
SZ & 26.41301 & 4.400309 & 6.002536 & 0.0000 \\
\hline \hline R-squared & 0.969727 & Mean dependent var & 11.09412 \\
Adjusted R-squared & 0.964051 & S.D. dependent var & 11.58667 \\
S.E. of regression & 2.196856 & Akaike info criterion & 4.573080 \\
Sum squared resid & 154.4376 & Schwarz criterion & 4.871668 \\
Log likelihood & -82.17505 & Hannan-Quinn criter. & 4.680211 \\
F-statistic & 170.8426 & Durbin-Watson stat & 1.242644 \\
Prob(F-statistic) & 0.000000 & & \\
\hline \hline
\end{tabular}

Figure 5.Multiple linear regression result

The explanation of the results of multiplelinear regression analysis is as follows:

1) T-Ststistic Result

\begin{tabular}{|c|c|}
\hline $\begin{array}{l}\text { Dependent } \\
\text { Variable }\end{array}$ & Effect to Independent Variables \\
\hline$X_{1}$ & $\begin{array}{c}\text { VAIC }^{\mathrm{TM}} \text { has no effect on ROA, p } \\
\text { value }>0.05\end{array}$ \\
\hline $\mathrm{X}_{2}$ & $\begin{array}{c}\text { VAIC }^{\mathrm{TM}} \text { has an effect on BOPO, } \mathrm{p} \\
\text { value }<0.05\end{array}$ \\
\hline $\mathrm{X}_{3}$ & $\begin{array}{c}\text { VAIC }^{\mathrm{TM}} \text { has an effect on Liquidity, } \mathrm{p} \\
\text { value }<0.05\end{array}$ \\
\hline $\mathrm{X}_{4}$ & $\begin{array}{c}\text { VAIC }^{\mathrm{TM}} \text { has no effect on Loss Ratio, } \\
\text { p value }>0.05\end{array}$ \\
\hline $\mathrm{X}_{5}$ & $\begin{array}{c}\text { VAIC }^{\mathrm{TM}} \text { has no effect on Capital, } \mathrm{p} \\
\text { value }>0.05\end{array}$ \\
\hline $\mathrm{X}_{6}$ & $\begin{array}{c}\text { VAIC }^{\mathrm{TM}} \text { has an effect on } \mathrm{Si}, \mathrm{p} \text { value }< \\
0.05\end{array}$ \\
\hline
\end{tabular}

Figure 6.T-Statistic result

\section{2) Beta Coefficient Result}

Among other independent variables, SIZE has the most positive effect on VAIC ${ }^{\mathrm{TM}}$, which is worth 26.41301 or it can be interpreted that each change in VAIC ${ }^{\mathrm{TM}}$ unit can result in changes in SIZE of $2641 \%$. While BOPO has a negative effect on VAIC ${ }^{\mathrm{TM}}$ which is worth 0.635461 .

3) R-Squared Coefficient Result 
With a value of 0.969727 , which means a set of independent variables can explain the dependent variable by $96.9727 \%$, meaning that there is a strong relationship between the independent variables and the dependent variable, while the remaining $3.0273 \%$ is explained by other variables not examined.

4) Adjusted R-Squared Coefficient Result

The R-squared value has been corrected by the standard error value to 0.964051 , while the standard error (S.E.) value of this regression is 2.196856 which is smaller than the standard deviation (S.D.) value of 11.58667 , so it can be interpreted as a predictor model valid regression model.

5) Simultaneity Test (F-Statistic)Result

The F-statistic value is 170.8426 with p-value is 0.00000 where $<0.05$ or below the critical limit of the study, so it can be concluded that the independent variable simultaneously influences the dependent variable.

e. Comparation With Previous Researches

Based on the results of multiple linear regression analysis that has been done, then the results will be compared with the results of previous studies so that the similarities and differences can be known with the research described in the following table:

\begin{tabular}{|l|c|c|c|}
\hline \multirow{2}{*}{ Researcher } & \multicolumn{3}{|c|}{ Comparison } \\
\cline { 2 - 4 } & $\begin{array}{c}\text { Type } \\
\text { Variable }\end{array}$ & Variabel & Result \\
\hline Chu et al [2] & Effect & ROA & Different \\
\hline $\begin{array}{l}\text { Santi Dwie } \\
\text { Lestari et al } \\
\text { [13] Effect }\end{array}$ & BOPO & Support \\
\hline $\begin{array}{l}\text { A.A. Ayu } \\
\text { Kemara Dewi } \\
\text { \& Ida Bagus } \\
\text { Badjra }\end{array}$ & Effect & SIZE & Support \\
\hline
\end{tabular}

Table I. Table Comparison of Previous Studies

Based on the comparison table above it can be explained that:

1) This research is different from the in this study found that ROA affects Intellectual Capital. This is very possible because use different research objects and data.

2) By using different periods of data and objects, this study supports the results that BOPO has an effect on Intellectual Capital Islamic banking companies in Indonesia

3) The research found that SIZE had an effect on Intellectual Capital so that this study supports these results.

\section{Conclusion}

The results of this study indicate that BOPO, Liquidity, and Size can affect Intellectual Capital of Islamic life insurance companies in Indonesia while ROA, VOC and Loss Ratio cannot affect Intellectual Capital of Islamic life insurance companies in Indonesia. This study still has limited objects, number of variables, number of data, period of data, and method of analysis so that further research is expected to add objects, variables, amount of data, data periods and other methods of analysis.

And the advice from research for this company is to increase the cost of training focused on marketing communication skills, front man desk, and public relations. In addition, it further 
enhances human resources to develop more organized and planned stages in building external and internal communication.

Suggestions for the next researcher are expected to be able to find other indicators as measuring devices of variables that will be meticulous and are expected to use different research methods to obtain more accurate data.

\section{References}

[1] H. Hasbi and B. Suryawardani, "Sistem Peringatan Dini sebagai Pendukung Kinerja Perusahaan Asuransi Syariah,” J. Keuang. dan Perbank., vol. 17, no. 2, pp. 243-252, 2013.

[2] S. K. W. Chu, K. H. Chan, K. Y. Yu, H. T. Ng, and W. K. Wong, "An Empirical Study of the Impact of Intellectual Capital on Business Performance," J. Inf. Knowl. Manag., vol. 10, no. 1, pp. 11-21, Mar. 2011.

[3] A. A. A. K. Dewi and I. B. Badjra, "Pengaruh Profitabilitas, Aktiva Tidak Berwujud, Ukuran Perusahaan, Dan Struktur Modal Terhadap Nilai Perusahaan," E-Jurnal Manaj., vol. 6, no. 4, pp. 2161-2190, 2017.

[4] R. Petty and J. Guthrie, "Intellectual capital literature review," J. Intellect. Cap., vol. 1, no. 2, pp. 155-176, Jun. 2000.

[5] A. Pulic, "Measuring The Performance Of Intellectual Potential In Knowledge Economy," in The 2nd McMaster Word Congress on Measuring and Managing Intellectual, 1998, pp. 1-20.

[6] T. Sawarjuwono and A. P. Kadir, "Intellectual Capital: Perlakuan, Pengukuran dan Pelaporan (Sebuah Library Research)," J. Akunt. dan Keuang., vol. 5, no. 1, pp. 35-37, 2003.

[7] A. A. Ousama and A. H. Fatima, "The determinants of voluntary disclosure in the annual reports by Shariah-Approved companies listed on Bursa Malaysia," in IIUM International Accounting Conference, 2006, pp. 26-28.

[8] Abidin, "Upaya Mengembangkan Ukuran- ukuran Baru," Media Akunt., vol. 8, no. 7, pp. 46-47, 2000.

[9] T. A. Stewart, Capital Model Intellectual. Jakarta: Elex Media Komputindo, 2003.

[10] W. U. Rehman, A. R. Chaudhary, H. U. Rehman, and A. Zahid, "Intellectual capital performance and its impact on corporate performance: An empirical evidence from MODARABA sector of Pakistan,” Aust. J. Bus. Manag. Res., vol. 1, no. 5, 2011.

[11] B. R. Appuhami, "The impact of intellectual capital on investors' capital gains on shares: an empirical investigation of Thai banking, finance and insurance sector," Int. Manag. Rev., vol. 3, no. 2, pp. 14-25, 2007.

[12] H. Malik, "Determinants of insurance companies profitability: an analysis of insurance sector of Pakistan," Acad. Res. Int., vol. 1, no. 3, pp. 2223-9553, 2011.

[13] L. S. Dwie, H. Paramu, and H. Sukarno, "Pengaruh Intellectual Capital Terhadap Kinerja Keuangan Perbankan Syariah di Indonesia," J. Ekon. dan Keuang., vol. 20, no. 3, 2016. 